\title{
A systematic review of neuroprotective strategies after cardiac arrest: from bench to bedside (part II-comprehensive protection)
}

\author{
Lei Huang ${ }^{1,2}$, Patricia M Applegate ${ }^{3}$, Jason W Gatling ${ }^{1}$, Dustin B Mangus ${ }^{1}$, John Zhang ${ }^{1,2,4}$ \\ and Richard L Applegate $\|^{1 *}$
}

\begin{abstract}
Neurocognitive deficits remain a significant source of morbidity in survivors of cardiac arrest. We conducted a literature review of treatment protocols designed to evaluate neurologic outcome and survival following global cerebral ischemia associated with cardiac arrest. The search was limited to investigational therapies that were implemented either during cardiopulmonary resuscitation or after return of spontaneous circulation in studies that included assessment of impact on neurologic outcome. Given that complex pathophysiology underlies global brain hypoxic ischemia following cardiac arrest, neuroprotective strategies targeting multiple stages of neuropathologic cascades should promise to improve survival and neurologic outcomes in cardiac arrest victims. In Part II of this review, we discuss several approaches that can provide comprehensive protection against global brain injury associated with cardiac arrest, by modulating multiple targets of neuropathologic cascades. Pharmaceutical approaches include adenosine and growth factors/hormones including brain-derived neurotrophic factor, insulin-like growth factor-1 and glycine-proline-glutamate, granulocyte colony stimulating factor and estrogen. Preclinical studies of these showed some benefit but were inconclusive in models of global brain injury involving systemic ischemia. Several medical gases that can mediate neuroprotection have been evaluated in experimental settings. These include hydrogen sulfide, hyperbaric oxygen and molecular hydrogen. Hyperbaric oxygen and molecular hydrogen showed promising results; however, further investigation is required prior to clinical application of these agents in cardiac arrest patients.
\end{abstract}

Keywords: Cardiac arrest, Global brain injury, Comprehensive neuroprotection, Model, Pharmaceutical, Hyperbaric oxygen, Hydrogen sulfide, Hydrogen gas

\section{Introduction}

According to the 2013 update of Heart Disease and Stroke Statistics from the American Heart Association (AHA), out-of-hospital cardiac arrest (CA) has an overall incidence of 359,400 yearly and a low $9.5 \%$ survival rate [1]. Additionally, more than 200,000 adults have inhospital CA each year and only $23.9 \%$ of these patients survive to hospital discharge [1]. For those patients who do survive to hospital discharge, neurologic injury remains a source of significant morbidity. Nearly $70 \%$ of patients still have moderate to severe cognitive deficits

\footnotetext{
* Correspondence: rapplegate@llu.edu

'Department of Anesthesiology, Loma Linda University School of Medicine, 11041 Campus Street, Loma Linda, CA, USA

Full list of author information is available at the end of the article
}

at three months after CA [2]. The persistence of unfavorable neurologic outcomes, despite advances in cardiopulmonary resuscitation (CPR) prompted AHA to emphasize brain injury in relation to cardiac arrest by proposing "cardiopulmonary-cerebral resuscitation" in its 2000 Guidelines for Cardiopulmonary Resuscitation and Emergency Cardiovascular Care [3]. Therapeutic strategies targeting brain injury after CA are thus an important area for basic and clinical research. Over decades, however, a host of putative neuroprotective strategies failed to demonstrate clinical benefit except for mild therapeutic hypothermia [4]. New neuroprotective approaches are warranted in the setting of global brain injury associated with CA. 
The complex series of pathophysiological changes contributing to global brain hypoxic ischemia following CA have been summarized in Part I of this review. Whole body ischemia/reperfusion injury and/or systemic inflammatory responses increase the pathologic complexity of brain injury following $\mathrm{CA}$, which in turn increases the difficulty and complexity in the search for an effective neuroprotective agent. In this context, a specific therapy targeting multiple stages of neuropathology cascades should provide promise to improve survival and neurologic outcomes in $\mathrm{CA}$ victims. Indeed, the successful translation of therapeutic hypothermia $(\mathrm{TH})$ to $\mathrm{CA}$ patients is attributed to the multiple neuroprotective effects of $\mathrm{TH}$ against global brain ischemia [5].

\section{Literature search method}

A literature search was conducted of articles indexed in Medline and published between 1980 and October 2013 using combination of keywords including "brain injury", "cardiac arrest", "neuroprotection", "cerebral protection", "cardiopulmonary resuscitation", "global ischemia”, "global cerebral ischemia", and "global brain ischemia" (Table 1). Bibliographies of relevant articles were crossreferenced for pertinent articles. Articles were selected for review if postulated mechanisms of neuroprotection and some measure of neurologic outcomes were included. Only neuroprotective strategies tested in animal models relevant to global brain ischemia associated with CA were reviewed. Case reports, pediatric studies and articles not written in English were excluded. Studies of therapies administered before CA were not included as our goal was to investigate potential therapies to improve neurologic outcome that can be employed in the clinical setting (during or after CPR). Similarly, the many studies related to neuroprotection from anesthetic

Table 1 Search terms used to perform literature search

\begin{tabular}{ll}
\hline Database & Search terms \\
\hline PubMed & Brain injury \\
& Cardiac arrest \\
& Neuroprotection \\
& Neuroprotection \\
& Cerebral protection \\
& Cardiopulmonary resuscitation \\
& Global ischemia \\
& Gglobal cerebral ischemia \\
& Global brain ischemia \\
& These terms were searched in \\
& combinations as subject headings \\
& and keywords simultaneously. \\
& Articles were limited to those \\
printed or translated into English
\end{tabular}

agents were not included, as administration of anesthetic agents during or immediately after CPR may be impractical or associated with undesirable hemodynamic effects. Due to the pathophysiologic differences between focal and global cerebral ischemia, the extensive literature regarding neuroprotective strategies in focal cerebral ischemia is acknowledged but not included in this review. In this part, a total of 17 preclinical studies were reviewed. We focus on several strategies that demonstrate comprehensive neuroprotective mechanisms evaluated in the setting of whole body and global brain ischemia associated with CA. Due to the limited numbers of publications in this area, we included pre-clinical studies using animal models of global brain injury involving bilateral carotid occlusion along with systemic hypotension.

\section{Review}

In addition to global brain ischemia and reperfusion, CA and resuscitation are associated with whole body ischemia/reperfusion injury and/or systemic inflammatory responses. These processes increase the pathological complexity of brain injury following CA. Therapeutic interventions targeting multiple stages of neuropathologic cascades that have been investigated can be separated into PHARMACEUTICAL APPROACHES and GASMEDIATOR APPROACHES (Table 2).

\section{Pharmaceutical approaches \\ Adenosine}

Adenosine was proposed in the late 1980's to be an endogenous neuroprotective molecule with multiple functions [6]. Effects of adenosine and its receptor agonists include reducing the release of excitotoxic neurotransmitters, vasorelaxation, anti-inflammatory effects, reduction of metabolism, scavenging free radicals and moderate reduction of brain temperature [6,7]. Only one pre-clinical study evaluated its treatment effects in the setting of global brain injury associated with CA [8]. In a rat model of CA and CPR, post-ischemic administration of adenosine $(7.2 \mathrm{mg} / \mathrm{kg})$ was associated with a transient increase in brain total adenylates, hypothermia, increased postischemia brain blood flow and reduced brain edema and delayed CA1 neuronal loss in the hippocampus [8].

In the brain, adenosine acts as a neurotransmitter through activation of four specific G-protein-coupled adenosine (A) receptors: A1, A2A, A2B and A3 receptors [9]. The A1 receptor mediates neuroprotection, mostly by blockade of $\mathrm{Ca}^{2+}$ influx, which results in inhibition of glutamate release and reduction of glutamate excitatory effects at a postsynaptic level [10]. Unfortunately, selective activation of $\mathrm{A} 1$ receptors as a therapeutic approach for brain injury was hampered by major cardiovascular side effects such as bradycardia and hypotension [6,9]. Given that selective activation of $\mathrm{A} 2 \mathrm{~A}$ and $\mathrm{A} 3$ receptors 


\begin{tabular}{|c|c|c|c|c|c|c|c|c|}
\hline Therapy & Proposed mechanism & Study subject & Blind & $\begin{array}{l}\text { Placebo } \\
\text { control }\end{array}$ & $\begin{array}{l}\text { Random } \\
\text { assignment }\end{array}$ & Delivery route & $\begin{array}{l}\text { Effect: } \\
\text { Positive } \\
\text { Negative } \\
\text { Neutral }\end{array}$ & Outcomes evaluated \\
\hline \multicolumn{9}{|c|}{ Pharmaceutical approaches } \\
\hline Adenosine [8] & $\begin{array}{l}\text { Blockade } \mathrm{Ca}^{2+} \text { influx } \\
\text { [10] Hypothermia [8] }\end{array}$ & Rats & Not mentioned & Yes & Yes & Intravenous & Positive & $\begin{array}{l}\text { Survival, regional blood } \\
\text { flow, brain edema, } \\
\text { metabolite assay, } \\
\text { neurohistopathology, } \\
\text { temporalis muscle } \\
\text { temperature }\end{array}$ \\
\hline BDNF [14] & $\begin{array}{l}\text { Up regulate Bcl-2, suppress } \\
\text { TNF-alpha, increase IL-10, } \\
\text { reduce excitotoxicity, } \\
\text { promote neural regeneration } \\
\text { and axonal sprouting/ } \\
\text { synaptogenesis [11] }\end{array}$ & Rats & Not mentioned & Yes & Not mentioned & $\begin{array}{l}\text { Intracerebro- } \\
\text { ventricular }\end{array}$ & Neutral & $\begin{array}{l}\text { Survival, neurologic } \\
\text { function, neurohistopathology }\end{array}$ \\
\hline \multirow[t]{2}{*}{ IGF-1/GPE [19,21] } & $\begin{array}{l}\text { Anti-apoptosis, modulation } \\
\text { of BBB permeability and } \\
\text { neuronal excitability [17] }\end{array}$ & Rats & Not mentioned & Yes & Yes & Intravenous [19] & $\begin{array}{l}\text { Positive when } \\
\text { combined with TH [19] }\end{array}$ & Neurologic function [19] \\
\hline & HIF-1 alpha activation [18] & & & & & $\begin{array}{l}\text { Intracerebro- } \\
\text { ventricular [21] }\end{array}$ & $\begin{array}{l}\text { Short-term: Positive; } \\
\text { Long-term: Neutral [21] }\end{array}$ & Neurohistopathology [18,21] \\
\hline \multirow[t]{2}{*}{ G-CSF $[25,26]$} & \multirow{2}{*}{$\begin{array}{l}\text { Anti-apoptosis, anti- } \\
\text { inflammation and } \\
\text { enhance neurogenesis [23] }\end{array}$} & \multirow[t]{2}{*}{ Rats } & \multirow[t]{2}{*}{ Not mentioned } & \multirow[t]{2}{*}{ Yes } & Yes [25] & Subcutaneous [25] & Positive [25] & $\begin{array}{l}\text { Survival, neurologic function, } \\
\text { neurohistopathology }[25,26]\end{array}$ \\
\hline & & & & & $\begin{array}{l}\text { Not mentioned } \\
{[26]}\end{array}$ & $\begin{array}{l}\text { Intracerebro- } \\
\text { ventricular [26] }\end{array}$ & $\begin{array}{l}\text { Long-term: Negative } \\
\text { [26] }\end{array}$ & $\begin{array}{l}\text { p-STAT3, p-AKT1/2/3 } \\
\text { and p-ERK1/2 [25] }\end{array}$ \\
\hline \multirow[t]{3}{*}{ Estrogen [30-32] } & $\begin{array}{l}\text { Promote neuronal survival } \\
\text { and neurogenesis [29] }\end{array}$ & \multirow[t]{3}{*}{ Mice } & $\begin{array}{l}\text { Not mentioned } \\
{[30,31]}\end{array}$ & \multirow[t]{3}{*}{ Yes } & \multirow[t]{3}{*}{ Yes } & Intravenous [30,31] & \multirow[t]{3}{*}{ Positive } & $\begin{array}{l}\text { Neurological function } \\
\text { [31] Neurohistopathology [30-32] }\end{array}$ \\
\hline & $\begin{array}{l}\text { Increase expression } \\
\text { of SK2 [32] }\end{array}$ & & Yes [32] & & & $\begin{array}{l}\text { Subcutaneous } \\
{[31,32]}\end{array}$ & & \multirow{2}{*}{$\begin{array}{l}\text { Small-conductance } \\
\text { calcium-activated } \\
\text { potassium (SK2 and SK3) } \\
\text { channel transcripts, } \\
\text { electrophysiology [32] }\end{array}$} \\
\hline & Reduce excitoxicity $[33,34]$ & & & & & & & \\
\hline \multicolumn{9}{|c|}{ Gas-mediator approaches } \\
\hline \multirow[t]{2}{*}{$\mathrm{H}_{2} \mathrm{~S}[41-44]$} & $\begin{array}{l}\text { Increase level of } \\
\text { antioxidant glutathione } \\
\text { and/or scavenging oxygen } \\
\text { species, anti apoptosis and } \\
\text { anti-inflammation [37-39] }\end{array}$ & Mice [41-43] & $\begin{array}{l}\text { Not mentioned } \\
{[41,42,44]}\end{array}$ & Yes & Not mentioned & Intravenous & $\begin{array}{l}\text { Positive when } \\
\text { delivered at or prior } \\
\text { to CPR initiation [41-43] }\end{array}$ & $\begin{array}{l}\text { Survival, neurologic function, } \\
\text { neurohistopathology [41-44] }\end{array}$ \\
\hline & Open K KTP chanel [35-37] & Pigs [44] & Yes [43] & & & & $\begin{array}{l}\text { Neutral when delivered } \\
10 \text { min after CPR [41] }\end{array}$ & $\begin{array}{l}\text { Myocardial function, } \\
\text { serum nitrite/nitrate levels } \\
\text { and hydrogen peroxide } \\
\text { level, cardiac }\end{array}$ \\
\hline
\end{tabular}


Table 2 Summary of comprehensive neuroprotective strategies for global cerebral ischemia associated with cardiac arrest (Continued)

\begin{tabular}{|c|c|c|c|c|c|c|c|c|}
\hline & & & & & & & & $\begin{array}{l}\text { mitochondrial } \\
\text { swelling [41] }\end{array}$ \\
\hline & \multirow[t]{2}{*}{$\begin{array}{l}\text { Enhance NMDA } \\
\text { receptors [38] }\end{array}$} & & & & & & Negative [44] & $\begin{array}{l}\text { Diffusion weighted } \\
\text { imaging and MMP-9 } \\
\text { activity [42] }\end{array}$ \\
\hline & & & & & & & & $\begin{array}{l}\text { Cardiac output, heart } \\
\text { rate and pulmonary } \\
\text { arterial pressure [44] }\end{array}$ \\
\hline \multirow[t]{3}{*}{$\mathrm{HBO}[52,53]$} & \multirow{3}{*}{$\begin{array}{l}\text { Attenuation of oxidative } \\
\text { and inflammatory injury, } \\
\text { inhibition of apoptosis, } \\
\text { enhance neurogenesis } \\
{[47,48]}\end{array}$} & Dogs [52] & \multirow[t]{3}{*}{ Not mentioned } & \multirow[t]{3}{*}{ Yes } & Yes [52] & \multirow[t]{3}{*}{ Inhaled } & \multirow[t]{3}{*}{ Positive } & $\begin{array}{l}\text { Neurologic function [52] } \\
\text { Neurohistopathology }[52,53]\end{array}$ \\
\hline & & Rats [53] & & & $\begin{array}{l}\text { Not mentioned } \\
{[53]}\end{array}$ & & & $\begin{array}{l}\text { Oxygen extraction ratio } \\
\text { and cerebral oxygen } \\
\text { delivery/utilization [52] }\end{array}$ \\
\hline & & & & & & & & $\begin{array}{l}\text { Expression of Nogo-A/B, } \\
\text { Nogo receptors and } \\
\text { RhoA expressions [53] }\end{array}$ \\
\hline \multirow[t]{3}{*}{$\mathrm{H}_{2}[57,58]$} & \multirow{3}{*}{$\begin{array}{l}\text { Anti-oxidant, anti } \\
\text { inflammation and } \\
\text { anti-apoptosis }[55,56]\end{array}$} & Rats [57] & \multirow[t]{3}{*}{ Not mentioned } & \multirow[t]{3}{*}{ Yes } & \multirow[t]{3}{*}{ Yes } & Inhaled [57] & \multirow[t]{3}{*}{ Positive } & $\begin{array}{l}\text { Survival, neurologic function, } \\
\text { neurohistopathology }[57,58]\end{array}$ \\
\hline & & Rabbit [58] & & & & \multirow[t]{2}{*}{ Intraperitoneal [58] } & & $\begin{array}{l}\text { Myocardial function, } \\
\text { cardiomyocyte } \\
\text { degeneration, lung } \\
\text { edema and systemic } \\
\text { inflammatory response [57] }\end{array}$ \\
\hline & & & & & & & & $\begin{array}{l}\text { Plasma 8-OHDG } \\
\text { and MDA level [58] }\end{array}$ \\
\hline
\end{tabular}


mediated glutamate release and/or microglia activation and cell death, respectively, development of selective antagonists targeting A2A and A3 may offer a possible treatment for brain disorders via anti-excitoxicity, anti inflammation and anti-apoptosis mechanisms [10,11]. Therapeutic applications of discrete adenosine ligands need to be further explored in the setting of global brain ischemia following CA.

\section{Growth factors/hormones}

Under focal ischemic conditions in the brain, administration of several types of exogenous growth factor/hormones has been shown to be neuroprotective. Limited animal studies evaluated their effects in global brain ischemia secondary to CA. However, the neuroprotective effects were not as robust as that found in cerebral ischemia that does not concurrently involve complete systemic circulatory stasis. Furthermore, a short half-life and a low rate of transport through the blood brain barrier $(\mathrm{BBB})$ could challenge clinical applications of growth factor/hormones for brain protection.

1. Brain-derived neurotrophic factor (BDNF) BDNF is a neurotrophic factor in the nerve growth factor family. It acts as a potent neuronal survival modulator through the tropomyosin-related kinase receptor type $B$ [12]. The neuroprotective role of BDNF has been shown in ischemic injury including focal brain ischemia, hypoxic-ischemia and global brain ischemia induced by four vessels occlusions $[12,13]$. The multiple protective roles of BNDF against ischemic brain injury may involve 1) anti-apoptosis by up-regulating B-cell lymphoma-2 (Bcl-2) and inhibiting intracellular calcium overload; 2) anti-inflammation by suppressing proinflammatory tumor necrosis factor (TNF)- $\alpha$ expression while increasing anti-inflammatory interleukin (IL)-10 expression; 3) attenuating neurotoxicity mediated by $\mathrm{N}$-methyl-D-aspartate (NMDA) and glutamate; 4) promoting neural regeneration and increasing axonal sprouting and synaptogenesis as well as angiogenesis [12]. However, BDNF failed to provide neurological benefit in a rat model of 6 minute CA and CPR [14]. Neurologic deficits and neurohistopathology at 1, 3 and 7 days post-CA were not different between BDNF treated and placebo treated rats.

2. Insulin-like growth factor-1 (IGF-1) and glycine-proline-glutamate (GPE)

IGF-1 participates in somatic and vascular growth, glucose hemostasis and brain development $[15,16]$. By binding to its specific receptor and binding proteins, IGF-1 exerts pleiotropic neuroprotection including potent antiapoptotic properties, modulation of BBB permeability and neuronal excitability [17]. Activation of hypoxia-inducible factor (HIF)- $1 \alpha$ might also be part of the mechanism underlying IGF-1 promoted cell survival after cerebral ischemia [18]. In a rat model of bilateral carotid occlusion and systemic hypotension, the combination therapy of IGF-1 and hypothermia protected the brain against global ischemic injury. After 8 minutes of untreated global brain ischemia, at the onset of reperfusion one of three treatment regimens was initiated: intravenous (IV) administration of $0.6 \mathrm{U} / \mathrm{kg}$ IGF-1 alone; hypothermia $\left(32^{\circ} \mathrm{C}\right.$ for $\left.4 \mathrm{~h}\right)$ alone; or combined IGF-1 with hypothermia. Only IGF-1 combined with hypothermia preserved hippocampal CA1 structure and improved neurological function compared to non-treated rats [19].

GPE is a bioactive cleavage product from $\mathrm{N}$-terminal IGF-1 and is also protective against ischemic brain injury [20]. The multiple mechanisms of GPE may be modulation of inflammation, promotion of astrocytosis, inhibition of apoptosis and vascular remodeling [20]. The effects of IGF-1 and GPE were compared in a rat model of CA and CPR [21]. Rats were randomized to receive intracerebroventricular (ICV) IGF-1, GPE, or placebo as a constant infusion for up to 7 days post-ischemia. Neurohistopathologic staining of the CA1 region of the hippocampus was performed at 3, 7 and 14 days. The early significant reduction in the number of apoptotic cells was only observed in the GPE group at 3 days, but this did not persist to 7 or 14 days. From a translational point of view, GPE is a small neuropeptide that can pass BBB easily, thus giving advantages over growth factors in the treatment of brain injury. Nevertheless, it requires a continuous IV infusion to maintain stable central uptake due to the extremely short half-life of GPE [20].

3. Granulocyte colony stimulating factor (G-CSF) $\mathrm{G}-\mathrm{CSF}$ is an endogenous peptide hormone of the hematopoietic system that has been evaluated in clinical trials for ischemic stroke [22,23]. By binding to G-CSF receptors in the brain, G-CSF has neuroprotective effects through anti-apoptosis and anti-inflammation as well as through enhancing neurogenesis [24]. A rat model of global brain ischemia induced by 2 -vessel occlusion with hemorrhagic hypotension demonstrated the neuroprotective effect of G-CSF [25]. In a rat CA and CPR model, ICV administration of G-CSF (7 or 14 days), however, did not benefit survival, neurobehavioral testing or histopathology over 14 days post-resuscitation [26]. Instead, application of G-CSF increased neuronal damage at 14 days after CA [26]. 


\section{Estrogen}

Estrogen can bind to two classic nuclear receptors, namely, estrogen receptor (ER)- $\alpha$ and ER- $\beta$, to produce physiologic and neuroprotective effects [27]. A number of studies have demonstrated that estrogen is neuroprotective in brain injury $[27,28]$. Multiple cellular pathways of cell protection have been associated with estrogen [27]. These involve extracellular signal-regulated kinase/mitogen activated protein kinase signaling and cross talking with IGF-1, which leads to cAMP responsive element binding protein phosphorylation and subsequent neuronal survival and neurogenesis following ischemic insult [29].

Several preclinical studies were performed to evaluate the neuroprotective effect of estrogen against global brain ischemia. In a mouse model of CA (10 minutes) and CPR, different single IV injection dosages of estrogen $(0.5,2.5,12.5,25$, or 50 micrograms) acutely after resuscitation did not benefit histopathology within hippocampi at 3 days post-resuscitation [30]. But the lowest dose of estrogen resulted in attenuated neuronal injury in the rostral and caudal caudoputamen regions. In a follow-up study, the same group demonstrated the neuroprotection of long-term administration of estrogen, which was most likely mediated by ER- $\beta$ [31]. They first randomized male mice to receive $17 \beta$ estradiol (E2, IV loading dose of 0.5 or 2.5 micrograms followed by 12.6 micrograms administered by subcutaneous implant for 3 days) or placebo after 10 minutes of CA followed by CPR. E2 at low or high dose had a neuroprotective effect on the rostral and caudal caudoputamen, but no effects in the hippocampal CA1 region. Neurologic functional recovery was only significant on day 3 with the higher loading dose. Secondly, they tested estrogen receptor (ER) agonist specific for the $\alpha$ or $\beta$. The ER- $\beta$, but not ER- $\alpha$, agonist showed improved neuronal survival in striatum and hippocampal CA1 compared to placebo.

Independent of ER- $\alpha$ and- $\beta, G$ protein-coupled estrogen receptor $1 / \mathrm{G}$-protein-coupled receptor 30 (GPER1/GPR30) is a recently identified membrane receptor that binds estrogen with high affinity [32]. In a mouse model of $\mathrm{CA}$, chronic treatment of male mice with GPR 30 agonist G1 decreased neuronal injury to an extent comparable to estrogen treatment. The increased expression of small-conductance calcium-activated potassium channel 2 (SK2) by G1 could protect neurons from ischemic injury [32]. Other studies also suggest that GPR30 is involved in

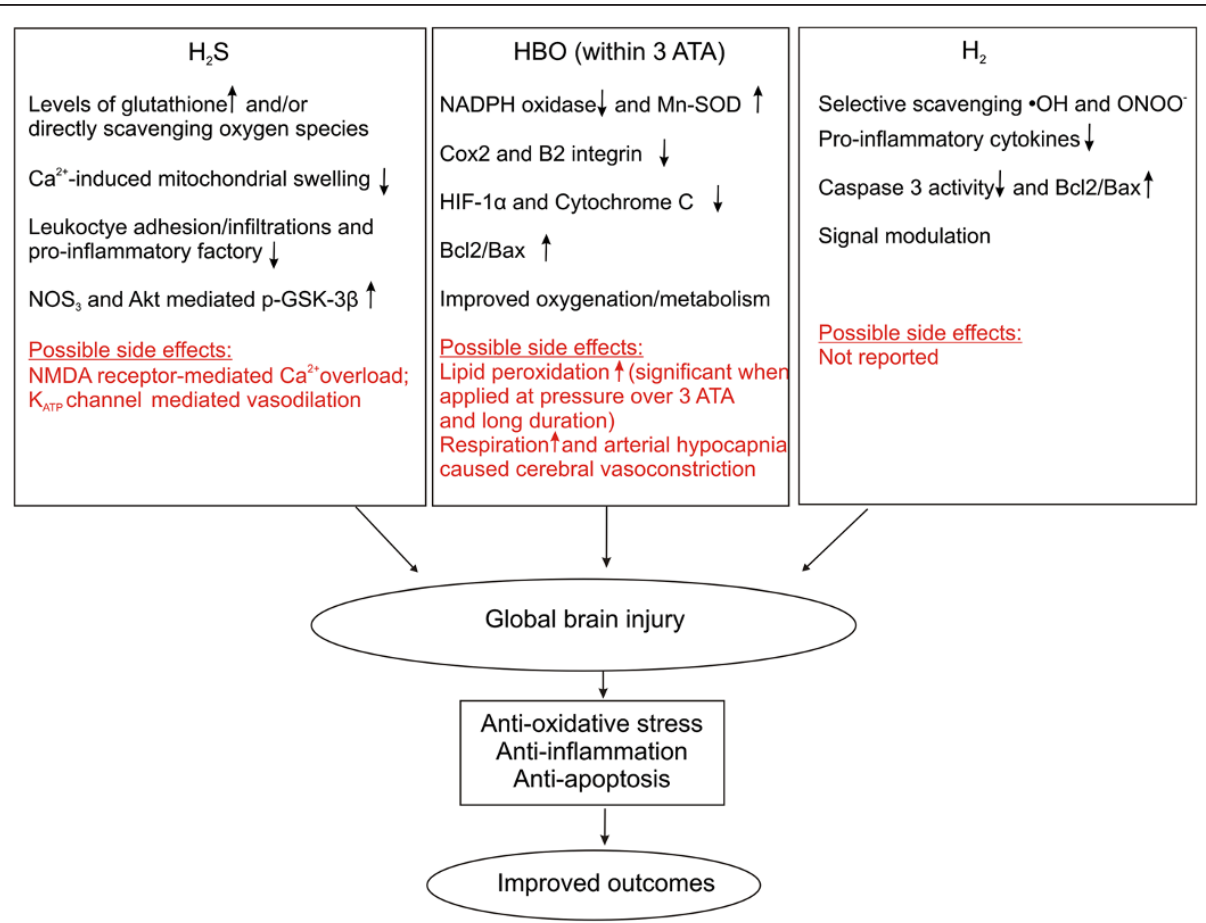

Figure 1 Neuroprotective mechanisms of gas-mediated approaches after resuscitation from cardiac arrest. Hydrogen sulfide $\left(\mathrm{H}_{2} \mathrm{~S}\right)$, hyperbaric oxygen $(\mathrm{HBO})$ and hydrogen gas $\left(\mathrm{H}_{2}\right)$ exert anti-oxidant, anti-inflammation and anti-apoptosis effects through regulation of variable signaling pathways. Such comprehensive brain protection leads to improved outcomes in the setting of global brain injury associated with cardiac arrest. 
estrogen neuroprotection through depression of the NMDA receptor 2B (NR2B)-containing NMDA receptors, thus reducing excitoxicity $[33,34]$. Developing agonists specifically targeting GPR may provide a promising pharmaceutical approach for neuroprotection.

\section{Gas-mediator approaches}

Gas-mediators exert whole brain protection through comprehensive and complementary mechanisms (Figure 1). Favorable biomembrane permeability renders them attractive alternatives for treatment of global ischemia following CA.

\section{Hydrogen sulfide}

Hydrogen sulfide $\left(\mathrm{H}_{2} \mathrm{~S}\right)$ was originally known as a toxic gas and environmental pollutant. However, there has been growing interest in the potential role of $\mathrm{H}_{2} \mathrm{~S}$ as an endogenous signaling molecule: a third gasotransmitter $[35,36]$. By opening ATP-sensitive potassium ( $\left.\mathrm{K}_{\mathrm{ATP}}\right)$ channels, endogenous $\mathrm{H}_{2} \mathrm{~S}$ acts as a vasorelaxant [35-37]. A number of preclinical studies suggested exogenous low concentration $\mathrm{H}_{2} \mathrm{~S}$ protects cells from oxidative stress by increasing levels of glutathione (a cellular major and potent antioxidant) and/or directly scavenging oxygen species [38]. It also exerts anti-apoptotic and antiinflammation effects [37,39]. In addition, $\mathrm{H}_{2} \mathrm{~S}$ facilitates the induction of hippocampal long-term potentiation by enhancing the activity of NMDA receptors [40]. In animal studies of global ischemia brain injury, $\mathrm{H}_{2} \mathrm{~S}$ or $\mathrm{H}_{2} \mathrm{~S}$ donors provided mixed results. Although $\mathrm{H}_{2} \mathrm{~S}$ can protect against inflammation, it may also be involved in intracellular calcium overload and worsen secondary neuronal injury $[35,36,39]$. These data suggested that $\mathrm{H}_{2} \mathrm{~S}$ may have beneficial and/or detrimental effects depending on what pathological state and/or what phase in a certain pathological state it is administered.

\section{Sodium sulfide, sodium hydrogen sulfide}

In mouse model of CA and CPR, administration (IV) of sodium sulfide $\left(\mathrm{Na}_{2} \mathrm{~S}\right.$, a hydrogen sulfide donor) $0.55 \mathrm{mg} / \mathrm{kg}$ at CPR initiation significantly improved survival and neurological deficits at 24 hours [41]. It also significantly decreased apoptosis in the hippocampus, and prevented myocardial dysfunction [41]. Delaying $\mathrm{Na}_{2} \mathrm{~S}$ administration to 10 minutes after CPR was also investigated but did not confer the same advantages as when administered at CPR initiation. No formal long-term analysis was performed in this study, but pilot studies show a significant long-term survival advantage in treatment group mice. A similar study investigated the mechanism by which by sodium hydrogen sulfide (NaHS; another hydrogen sulfide donor) conferred benefit [42]. Study methods were similar to $\mathrm{Na}_{2} \mathrm{~S}$ studies, but data was collected over
10 days and abnormal water diffusion in the brain was investigated using hyperintense diffusion-weighted imaging. Mice treated with NaHS had significantly improved 10-day survival, neurological outcome, and reduced brain water diffusion. Results differed in a mouse study utilizing a very similar protocol [43]. At CPR initiation, $\mathrm{Na}_{2} \mathrm{~S}$ was administered $(0.5 \mathrm{mg} / \mathrm{kg} \mathrm{IV}$ bolus) and continued as an infusion ( $1 \mathrm{mg} / \mathrm{kg} / \mathrm{hr}$ ) for 6 hours. The only significant difference was better neurological function scoring at 3 days in mice treated with $\mathrm{Na}_{2} \mathrm{~S}$. No other differences were seen between groups with respect to neurological function or neurohistopathology.

In contrast, researchers using a pig model of prolonged $\mathrm{CA}$ and CPR reported detrimental effects. $\mathrm{Na}_{2} \mathrm{~S}$ ( $1 \mathrm{mg} / \mathrm{kg}$ or $0.3 \mathrm{mg} / \mathrm{kg}$ ) injection and infusion given at 1 min after starting CPR did not improve initial resuscitation success. It further compromised early postresustication hemodynamics by reducing cardiac output, heart rate and pulmonary arterial pressure [44]. Such deleterious outcome was more significant in the high dose $\mathrm{Na}_{2} \mathrm{~S}$ group. $\mathrm{H}_{2} \mathrm{~S}$ mediated cerebral ischemia damage has been attributed to increased excitotoxicity through activating NMDA receptors in experimental focal ischemia [45] or due to its vasodilatation effect [44]. These conflicting results may be due to differences in drug administration time between the rodent model (at CPR initiation) and porcine model ( 1 minute after starting $\mathrm{CPR}$ ). It suggests that the temporal window of opportunity for improving the outcome of CA/CPR is relatively narrow and may require delivering $\mathrm{Na} 2 \mathrm{~S}$ immediately after reperfusion. This feature echoes a previous study of ischemic postconditioning that found the delay of onset of postconditioning by only 1 minute aborts protection in rabbit heart [46].

\section{Hyperbaric oxygen (HBO)}

$\mathrm{HBO}$ at low pressure (within 3 ATA) has been shown to ameliorate brain injury in a variety of animal models including focal cerebral ischemia, neonatal hypoxia-ischemia and subarachnoid hemorrhage [47]. Possible neurotoxicity was only found when $\mathrm{HBO}$ was applied at high pressure (>3ATA) and long duration [47]. Adverse effects include increased spontaneous respiratory rate that can lead to arterial hypocapnia with reduced cerebral blood flow, increased lipid peroxidation and seizures [47]. The multiple mechanisms of $\mathrm{HBO}$ include enhancing tissue oxygenation/metabolism, reduction of oxidative stress, inflammation modulation, and inhibition of apoptosis as well as enhancing neurogenesis $[47,48]$. It suggests low pressure of $\mathrm{HBO}$ may provide a promising neuroprotective strategy for CA patients favoring neurological function recovery. Neuroprotective effects of $\mathrm{HBO}$ therapy have been reported in animal models of global brain ischemia induced 
by clamping of the ascending aorta and cavae [49], infusing Elliott's B solution into the subarachnoid space [50] and 4vessel occlusion [51].

Positive results were consistently observed in two studies using a global brain ischemia model involving whole body ischemia. In a dog model of $\mathrm{CA}$, animals were randomized to control or $\mathrm{HBO}$ after $\mathrm{CA}$ and resuscitation [52]. HBO was administered at 2.7 ATA for 60 minutes starting 1 hour after ROSC. The functional status of the dogs was significantly better and neuronal damage was significantly less in the HBO group at 1 day after ROSC. Cerebral oxygen extraction ratio was also significantly less in the HBO group. In a rat model of global brain ischemia with hypotension, HBO (3 ATA) applied at $1 \mathrm{~h}$ after ischemia for total of $2 \mathrm{~h}$ significantly reduced neuronal death in the CA1 region of the hippocampus and the cortex [53].

Additional preclinical studies using clinically relevant CA models are needed to establish the optimal dose and time for treatment as well as the safety of applying $\mathrm{HBO}$ treatment following $\mathrm{ROSC}$, particularly when intensive care is required.

\section{Molecular hydrogen $\left(\mathrm{H}_{2}\right)$}

Molecular hydrogen has previously been proposed as a novel selective hydroxyl radical and peroxynitrite scavenger in the treatment of focal brain ischemia [54]. Emerging evidence has demonstrated its protective a role in a variety of diseases through anti-oxidant, anti-inflammation and anti-apoptotic effects $[55,56]$. There is no risk of combustion at concentrations less than $4 \% \mathrm{H}_{2}$ [56]. In two animal models of global brain ischemia, hydrogen gas or hydrogen rich saline benefitted overall outcome after CA, including neurological function $[57,58]$. The protective effects have been shown to be comparable to therapeutic hypothermia [57].

Rats underwent 5 minutes of CA followed by CPR and were randomized to sham, control (ventilation with $98 \%$ $\mathrm{O}_{2}+2 \% \mathrm{~N}_{2}$ ), therapeutic hypothermia $(\mathrm{TH})$, hydrogen gas $\left(\mathrm{H}_{2}\right.$, ventilation with $\left.98 \% \mathrm{O}_{2}+2 \% \mathrm{H}_{2}\right)$, or $\mathrm{TH}+\mathrm{H}_{2}$ groups [57]. Twenty-four and seventy-two hour survival was significantly improved in rats treated with $\mathrm{H}_{2}, \mathrm{H}_{2}+$ $\mathrm{TH}$, or $\mathrm{TH}$ compared to controls. At 24 and 48 hours, the $\mathrm{H}_{2}, \mathrm{H}_{2}+\mathrm{TH}$, and $\mathrm{TH}$ groups were significantly better than the control group, and the $\mathrm{H}_{2}+\mathrm{TH}$ group was significantly better than the $\mathrm{TH}$ and $\mathrm{H}_{2}$ groups alone. Systemic inflammatory response measured at 2 hours post ROSC showed significantly reduced levels of IL- 6 in $\mathrm{H}_{2}$ and $\mathrm{H}_{2}+\mathrm{TH}$ groups compared to control or TH groups. Other significant effects seen with the $\mathrm{H}_{2}$ gas included maintaining low left ventricular end diastolic pressure during the first 2 hours after ROSC when compared to controls, decreased lung edema at 24 hours post-CA (levels same as sham rats), and attenuation of cardiomyocyte degeneration.
In rabbits subjected to CA followed by $\mathrm{CPR}$, intraperitoneal injection of $\mathrm{H}_{2}$ rich saline or placebo was done at CPR initiation [58]. Animals were assigned to sham (no CA); $\mathrm{CA}$; $\mathrm{CA}+$ low dose $\mathrm{H}_{2}\left(10 \mathrm{ml} / \mathrm{kg} ; \mathrm{CA}+\mathrm{H}_{2}\right.$ group 1$)$; and $\mathrm{CA}+$ high dose $\mathrm{H}_{2}$ rich saline $\left(20 \mathrm{ml} / \mathrm{kg} ; \mathrm{CA}+\mathrm{H}_{2}\right.$ group 2). Intraperitoneal $\mathrm{H}_{2}$ rich saline (low and high dose) significantly improved 72-hour survival, reduced neuronal injury, and reduced plasma oxidative markers. Neurologic functional recovery was significantly improved only with $20 \mathrm{ml} / \mathrm{kg} \mathrm{H}_{2}$ compared to controls at 72 hours.

$\mathrm{H}_{2}$ is cost-effective and has low toxicity with little drug-drug interaction. These features could make $\mathrm{H}_{2}$ administration an ideal neuroprotection approach that could be implemented during CPR and/or after ROSC.

\section{Conclusions}

Comprehensive neuroprotective strategies benefit global brain ischemia associated with cardiac arrest by targeting oxidative stress, cell apoptosis and inflammatory responses. Based on limited preclinical findings, gas-mediator strategies, particularly, $\mathrm{HBO}$ (within 3 ATA) and molecular $\mathrm{H}_{2}$, have shown promise for improving survival and neurologic outcomes when implemented either during or immediately after CPR. Such comprehensive brain protective therapies may provide advantages over selective treatment strategies that have been developed for global brain ischemia over the past few decades. To date, no clinical studies have been conducted to test these approaches in patients with global brain ischemia. Translational research is needed to further elucidate fundamental neuroprotective mechanisms and effective treatment protocols prior to clinical applications in the future.

\section{Abbreviations}

AHA: American Heart Association; BBB: Blood brain barrier; Bcl-2: B-cell lymphoma-2; BDNF: Brain-derived neurotrophic factor; $C A$ : Cardiac arrest; CPR: Cardiopulmonary resuscitation; ER: Estrogen receptor; GCSF: Granulocyte colony stimulating factor; GPE: Glycine-proline-glutamate; GPER: G protein-coupled estrogen receptor; GPR: G-protein-coupled receptor; $\mathrm{H}_{2}$ : Molecular hydrogen; $\mathrm{H}_{2} \mathrm{~S}$ : Hydrogen sulfide; $\mathrm{HBO}$ : Hyperbaric oxygen; HIF: Hypoxia-inducible factor; ICV: Intracerebroventricular; IGF-1: Insulin-like

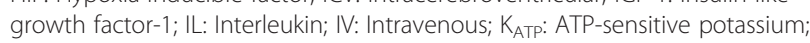
$\mathrm{Na}_{2} \mathrm{~S}$ : Sodium sulfide; NaHS: Sodium hydrogen sulfide; NMDA: N-methyl-Daspartate; NR2B: NMDA receptor 2B; ROSC: Restoration of spontaneous circulation; TH: Therapeutic hypothermia; TNF: Tumor necrosis factor.

\section{Competing interests}

The authors declare that they have no competing interest.

\section{Authors' contributions}

LH participated in design, literature search, evaluation of papers for inclusion and writing of this review. PA participated in evaluation of papers for inclusion and writing of this review. JG participated in literature search, evaluation of papers for inclusion and revision of this review. DM participated in literature search, evaluation of papers for inclusion and writing this review. JZ participated in the design and revision of this review. RA participated in design, literature search, evaluation of papers for inclusion and writing of this review. All authors read and approved the final manuscript. 


\section{Author details}

'Department of Anesthesiology, Loma Linda University School of Medicine, 11041 Campus Street, Loma Linda, CA, USA. ²Department of Basic Sciences, Division of Physiology and Anesthesiology, Loma Linda University School of Medicine, 11041 Campus Street, Loma Linda, CA 92354, USA. ${ }^{3}$ Department of Cardiology, Loma Linda University School of Medicine, 11201 Benton St, Loma Linda, CA 92354, USA. ${ }^{4}$ Department of Neurosurgery, Loma Linda University School of Medicine, 11041 Campus Street, Loma Linda, CA 92354, USA

Received: 27 January 2014 Accepted: 20 February 2014

Published: 20 May 2014

\section{References}

1. Go AS, Mozaffarian D, Roger VL, Benjamin E, Berry J, Borden W, Bravata D, Dai S, Ford E, Fox C, Franco S, Fullerton H, Gillespie C, Hailpern S, Heit J, Howard V, Huffman M, Kissela B, Kittner S, Lackland D, Lichtman J, Lisabeth L, Magid D, Marcus G, Marelli A, Matchar D, McGuire D, Mohler E, Moy C, Mussolino M: Heart disease and stroke statistics-2013 update: a report from the American Heart Association. Circulation 2013, 127:e6-e245.

2. Roine RO, Kajaste $S$, Kaste M: Neuropsychological sequelae of cardiac arrest. JAMA 1993, 269:237-242.

3. Part 1: introduction to the international guidelines 2000 for CPR and ECC: a consensus on science. Circulation 2000, 102:11-111.

4. Geocadin RG, Koenig MA, Jia X, Stevens RD, Peberdy MA: Management of brain injury after resuscitation from cardiac arrest. Neurol Clin 2008, 26:487-506. ix

5. Weng $Y$, Sun S: Therapeutic hypothermia after cardiac arrest in adults: mechanism of neuroprotection, phases of hypothermia, and methods of cooling. Crit Care Clin 2012, 28:231-243.

6. Phillis JW: Adenosine in the control of the cerebral circulation. Cerebrovasc Brain Metab Rev 1989, 1:26-54

7. von Lubitz DK: Adenosine and cerebral ischemia: therapeutic future or death of a brave concept? Eur J Pharmacol 1999, 371:85-102.

8. Xu K, Puchowicz MA, Lust WD, LaManna JC: Adenosine treatment delays Postischemic Hippocampal CA1 loss after cardiac arrest and resuscitation in rats. Brain Res 2006, 1071:208-217.

9. Abbracchio MP, Cattabeni F: Brain adenosine receptors as targets for therapeutic intervention in neurodegenerative diseases. Ann N Y Acad Sci 1999, 890:79-92.

10. Sachdeva S, Gupta M: Adenosine and its receptors as therapeutic targets: an overview. Saudi Pharm J 2013, 21:245-253.

11. Phillis JW, Goshgarian HG: Adenosine and neurotrauma: therapeutic perspectives. Neurol Res 2001, 23:183-189.

12. CHEN A, XIONG L-J, TONG Y, MAO M: The neuroprotective roles of Bdnf in hypoxic ischemic brain injury (Review). Biomed Rep 2013, 1:167-176.

13. Kiprianova I, Freiman TM, Desiderato S, Schwab S, Galmbacher R, Gillardon F, Spranger M: Brain-derived Neurotrophic factor prevents neuronal death and glial activation after global ischemia in the rat. $J$ Neurosci Res 1999, 56:21-27.

14. Popp E, Padosch SA, Vogel P, Schabitz WR, Schwab S, Bottiger BW: Effects of intracerebroventricular application of brain-derived Neurotrophic factor on cerebral recovery after cardiac arrest in rats. Crit Care Med 2004, 32:S359-S365

15. Anderson MF, Aberg MA, Nilsson M, Eriksson PS: Insulin-like growth factorand neurogenesis in the adult mammalian brain. Brain Res Dev Brain Res 2002, 134:115-122

16. Yakar S, Wu Y, Setser J, Rosen CJ: The role of circulating Igf-I: lessons from human and animal models. Endocrine 2002, 19:239-248.

17. Carro E, Trejo JL, Nunez A, Torres-Aleman I: Brain repair and neuroprotection by serum insulin-like growth factor I. Mol Neurobiol 2003, 27:153-162.

18. Chavez JC, LaManna JC: Activation of hypoxia-inducible factor-1 in the rat cerebral cortex after transient global ischemia: potential role of insulin-like growth factor-1. J Neurosci 2002, 22:8922-8931.

19. Lagina AT III, Calo L, Deogracias M, Sanderson T, Kumar R, Wider J, Sullivan $\mathrm{JM}$ : Combination therapy with insulin-like growth factor-1 and hypothermia synergistically improves outcome after transient global brain ischemia in the rat. Acad Emerg Med 2013, 20:344-351.

20. Guan J: Insulin-like growth factor -1 (lgf-1) derived neuropeptides, a novel strategy for the development of pharmaceuticals for managing ischemic brain injury. CNS Neurosci Ther 2011, 17:250-255.
21. Knapp J, Teschendorf $P$, Vogel P, Bruckner T, Bottiger BW, Popp E: Effects of intracerebroventricular application of insulin-like growth factor 1 and its $\mathrm{N}$-terminal tripeptide on cerebral recovery following cardiac arrest in rats. Resuscitation 2013, 84:684-689.

22. Schabitz WR, Schneider A: Developing granulocyte-colony stimulating factor for the treatment of stroke: current status of clinical trials. Stroke 2006, 37:1654. author reply 1655 .

23. Shyu WC, Lin SZ, Lee CC, Liu DD, Li H: Granulocyte colony-stimulating factor for acute ischemic stroke: a randomized controlled trial. CMAJ 2006, 174:927-933

24. Solaroglu I, Cahill J, Jadhav V, Zhang JH: A novel neuroprotectant granulocyte-colony stimulating factor. Stroke 2006, 37:1123-1128.

25. Matchett GA, Calinisan JB, Matchett GC, Martin RD, Zhang JH: The effect of granulocyte-colony stimulating factor in global cerebral ischemia in rats. Brain Res 2007, 1136:200-207.

26. Popp E, Rabsahl T, Schneider A, Russ N, Spohr F, Vogel P, Bottiger BW, Teschendorf $\mathrm{P}$ : Intracerebroventricular application of granulocyte colony-stimulating factor after cardiac arrest does not promote beneficial effects on cerebral recovery after cardiac arrest in rats. Resuscitation 2009, 80:478-483.

27. McCullough LD, Hurn PD: Estrogen and ischemic neuroprotection: an integrated view. Trends Endocrinol Metab 2003, 14:228-235.

28. Hurn PD, Macrae IM: Estrogen as a neuroprotectant in stroke. J Cereb Blood Flow Metab 2000, 20:631-652.

29. Lebesgue D, Chevaleyre V, Zukin RS, Etgen AM: Estradiol rescues neurons from global ischemia-induced cell death: multiple cellular pathways of neuroprotection. Steroids 2009, 74:555-561.

30. Noppens RR, Kofler J, Hurn PD, Traystman RJ: Dose-dependent neuroprotection by 17 beta-estradiol after cardiac arrest and cardiopulmonary resuscitation. Crit Care Med 2005, 33:1595-1602.

31. Noppens RR, Kofler J, Grafe MR, Hurn PD, Traystman RJ: Estradiol after cardiac arrest and cardiopulmonary resuscitation is neuroprotective and mediated through estrogen receptor-beta. J Cereb Blood Flow Metab 2009, 29:277-286.

32. Kosaka Y, Quillinan N, Bond C, Traystman R, Hurn P, Herson P: Gper1/Gpr30 activation improves neuronal survival following global cerebral ischemia induced by cardiac arrest in mice. Trans/ Stroke Res 2012, 3:500-507.

33. Liu SB, Zhang N, Guo YY, Zhao R, Shi TY, Feng SF, Wang SQ, Yang Q, Li XQ, Wu YM, Ma L, Hou Y, Xiong LZ, Zhang W, Zhao MG: G-protein-coupled receptor 30 mediates rapid neuroprotective effects of estrogen via depression of Nr2b-containing Nmda receptors. J Neurosci 2012, 32:4887-4900

34. Liu SB, Han J, Zhang N, Tian Z, Li XB, Zhao MG: Neuroprotective effects of oestrogen against oxidative toxicity through activation of $\mathrm{G}$-proteincoupled receptor 30 receptor. Clin Exp Pharmacol Physiol 2011, 38:577-585.

35. Li L, Rose P, Moore PK: Hydrogen sulfide and cell signaling. Annu Rev Pharmacol Toxicol 2011, 51:169-187.

36. Wang R: The gasotransmitter role of hydrogen sulfide. Antioxid Redox Signal 2003, 5:493-501

37. Vandiver M, Snyder SH: Hydrogen sulfide: a gasotransmitter of clinical relevance. J Mol Med (Berl) 2012, 90:255-263.

38. Kimura H: Hydrogen sulfide: from brain to gut. Antioxid Redox Signal 2010, 12:1111-1123.

39. Wang JF, Li Y, Song JN, Pang HG: Role of hydrogen sulfide in secondary neuronal injury. Neurochem Int 2014, 64C:37-47.

40. Abe $\mathrm{K}$, Kimura $\mathrm{H}$ : The possible role of hydrogen sulfide as an endogenous neuromodulator. J Neurosci 1996, 16:1066-1071.

41. Minamishima S, Bougaki M, Sips PY, Yu JD, Minamishima YA, Elrod JW, Lefer $\mathrm{DJ}$, Bloch KD, Ichinose F: Hydrogen sulfide improves survival after cardiac arrest and cardiopulmonary resuscitation via a nitric oxide synthase 3-dependent mechanism in mice. Circulation 2009, 120:888-896.

42. Kida K, Minamishima S, Wang H, Ren J, Yigitkanli K, Nozari A, Mandeville JB, Liu PK, Liu CH, Ichinose F: Sodium sulfide prevents water diffusion abnormality in the brain and improves long term outcome after cardiac arrest in mice. Resuscitation 2012, 83:1292-1297.

43. Knapp J, Heinzmann A, Schneider A, Padosch SA, Bottiger BW, Teschendor P, Popp E: Hypothermia and neuroprotection by sulfide after cardiac arrest and cardiopulmonary resuscitation. Resuscitation 2011, 82:1076-1080

44. Derwall M, Westerkamp M, Lower C, Deike-Glindemann J, Schnorrenberger NK, Coburn M, Nolte KW, Gaisa N, Weis J, Siepmann K, Hausler M, Rossaint 
$R$, Fries M: Hydrogen sulfide does not increase resuscitability in a porcine model of prolonged cardiac arrest. Shock 2010, 34:190-195.

45. Qu K, Chen CP, Halliwell B, Moore PK, Wong PT: Hydrogen sulfide is a mediator of cerebral ischemic damage. Stroke 2006, 37:889-893.

46. Cohen MV, Yang XM, Downey JM: The Ph hypothesis of postconditioning: staccato reperfusion reintroduces oxygen and perpetuates myocardial acidosis. Circulation 2007, 115:1895-1903.

47. Zhang JH, Lo T, Mychaskiw G, Colohan A: Mechanisms of hyperbaric oxygen and neuroprotection in stroke. Pathophysiology 2005, 12:63-77.

48. Matchett GA, Martin RD, Zhang JH: Hyperbaric oxygen therapy and cerebral ischemia: neuroprotective mechanisms. Neurol Res 2009, 31:114-121.

49. Takahashi M, Iwatsuki N, Ono K, Tajima T, Akama M, Koga Y: Hyperbaric oxygen therapy accelerates neurologic recovery after 15-minute complete global cerebral ischemia in dogs. Crit Care Med 1992, 20:1588-1594.

50. Mink RB, Dutka AJ: Hyperbaric oxygen after global cerebral ischemia in rabbits reduces brain vascular permeability and blood flow. Stroke 1995, 26:2307-2312.

51. Krakovsky M, Rogatsky G, Zarchin N, Mayevsky A: Effect of hyperbaric oxygen therapy on survival after global cerebral ischemia in rats. Surg Neurol 1998, 49:412-416.

52. Rosenthal RE, Silbergleit R, Hof PR, Haywood Y, Fiskum G: Hyperbaric oxygen reduces neuronal death and improves neurological outcome after canine cardiac arrest. Stroke 2003, 34:1311-1316.

53. Zhou C, Li Y, Nanda A, Zhang JH: Hbo Suppresses Nogo-a, Ng-R, or Rhoa expression in the cerebral cortex after global ischemia. Biochem Biophys Res Commun 2003, 309:368-376.

54. Ohsawa I, Ishikawa M, Takahashi K, Watanabe M, Nishimaki K, Yamagata K, Katsura K, Katayama Y, Asoh S, Ohta S: Hydrogen acts as a therapeutic antioxidant by selectively reducing cytotoxic oxygen radicals. Nat Med 2007, 13:688-694.

55. Dixon BJ, Tang J, Zhang JH: The evolution of molecular hydrogen: a noteworthy potential therapy with clinical significance. Med Gas Res 2013, 3:10.

56. Ohta S: Molecular hydrogen is a novel antioxidant to efficiently reduce oxidative stress with potential for the improvement of mitochondrial diseases. Biochim Et Biophys Acta-General Sub 1820, 2012:586-594.

57. Hayashida K, Sano M, Kamimura N, Yokota T, Suzuki M, Maekawa Y, Kawamura A, Abe T, Ohta S, Fukuda K, Hori S: H(2) gas improves functional outcome after cardiac arrest to an extent comparable to therapeutic hypothermia in a rat model. $J$ Am Heart Assoc 2012, 1:e003459.

58. Huang G, Zhou J, Zhan W, Xiong Y, Hu C, Li X, Li X, Li Y, Liao X: The neuroprotective effects of intraperitoneal injection of hydrogen in rabbits with cardiac arrest. Resuscitation 2013, 84:690-695.

doi:10.1186/2045-9912-4-10

Cite this article as: Huang et al.: A systematic review of neuroprotective strategies after cardiac arrest: from bench to bedside (part II-comprehensive protection). Medical Gas Research 2014 4:10

\section{Submit your next manuscript to BioMed Central and take full advantage of:}

- Convenient online submission

- Thorough peer review

- No space constraints or color figure charges

- Immediate publication on acceptance

- Inclusion in PubMed, CAS, Scopus and Google Scholar

- Research which is freely available for redistribution 